\title{
Perbandingan Kemampuan Pemahaman Matematis Siswa melalui Auditory Intellectualy Repetition dan Student Teams Achievement Division
}

\author{
Noni Siti Ridia ${ }^{1}$ dan Ekasatya Aldila Afriansyah ${ }^{2 *}$ \\ 1,2*Program Studi Pendidikan Matematika, Institut Pendidikan Indonesia \\ Jalan Pahlawan No. 32 Sukagalih, Garut, Jawa Barat, Indonesia \\ 1nonsridia26@gmail.com; ${ }^{2 *}$ ekasatyafriansyah@institutpendidikan.ac.id
}

Artikel diterima: 16-04-2019, direvisi: 06-09-2019, diterbitkan: 30-09-2019

\begin{abstract}
Abstrak
Kondisi pembelajaran saat ini cenderung kurang melibatkan siswa dalam proses pembelajaran meskipun siswa tampak mengikuti pembelajaran matematika dengan baik serta kemampuan pemahaman matematis siswa masih tergolong rendah. Strategi yang dapat melibatkan siswa dan meningkatkan kemampuan pemahaman dalam pembelajaran diantaranya model pembelajaran Auditory Intellectually Repetition dan Student Teams Achievement Division. Penelitian ini menggunakan metode penelitian kuasi eksperimen dengan desain Nonequivalent control group design. Sampel penelitian yang diambil sebanyak 59 orang dari dua kelas, yaitu kelas VII-D menggunakan model pembelajaran Auditory Intellectually Repetition sebanyak 29 orang dan kelas VII-E menggunakan model pembelajaran Student Teams Achievement Division sebanyak 30 orang. Instrumen yang digunakan yaitu tes kemampuan pemahaman matematis dan angket skala sikap. Hasil penelitian menunjukkan bahwa kemampuan pemahaman matematis siswa yang mendapatkan model pembelajaran Auditory Intellectually Repetition tidak lebih baik daripada siswa yang mendapatkan model pembelajaran kooperatif tipe Student Teams Achievement Division.

Kata Kunci: kemampuan pemahaman matematis, Auditory Intellectually Repetition, Student Teams Achievement Division, kuasi eksperimen.
\end{abstract}

\section{Comparing Students' Understanding Abilities through the Auditory Intellectually Repetition and the Student Teams Achievement Division}

\begin{abstract}
The current learning conditions tend to involve fewer students in the learning process even though students seem to follow mathematics learning well and the students' mathematical understanding ability is still relatively low. Strategies that can involve students and improve the ability to understand in learning include the Auditory Intellectually Repetition learning model and Student Teams Achievement Division. This research method uses quasi-experimental research with Nonequivalent control group design. The research sample was taken as many as 59 people from two classes, namely class VII-D using the Auditory Intelligence Repetition learning model as many as 29 people and class VII-E using 30 students Teams Achievement Division learning model. The instrument used is a mathematical understanding ability test and attitude scale questionnaire. The results showed that the students' mathematical comprehension ability who received the Auditory Intellectually Repetition learning model was no better than the students who received the cooperative learning model of Student Teams Achievement Division.

Keywords: Mathematics Understanding Ability, Auditory Intellectually Repetition, Student Teams Achievement Division, quasi-experiment.
\end{abstract}




\section{Pendahuluan}

Sumarmo dan Hendriana (2014) mencantumkan bahwa pembelajaran matematika bertujuan supaya siswa memiliki kemampuan sebagai berikut: 1) Memahami konsep matematika; 2) Menggunakan penalaran; 3) Memecahkan masalah; 4) Mengomunikasikan gagasan dengan simbol, tabel, diagram, atau media lain; dan 5) Memiliki sikap menghargai kegunaan matematika dalam kehidupan.

Berdasarkan poin kesatu bahwa untuk mencapai tujuan pembelajaran matematika salah satu aspek yang harus dimiliki yaitu kemampuan pemahaman matematis, karena kemampuan pemahaman matematis merupakan kemampuan utama yang harus dimiliki oleh peserta didik dan merupakan salah satu tujuan dari mata pelajaran matematika. Sebagaimana yang diungkapkan oleh Kurniawan (Ferdianto \& Ghanny, 2014), "Pengertian pemahaman matematis dapat dipandang sebagai proses dan tujuan dari suatu pembelajaran matematika".

Dalam pembelajaran matematika apabila siswa telah memahami suatu konsep atau materi yang disampaikan maka akan mempermudah siswa tersebut untuk mengikuti pembelajaran dan sebaliknya. Kemampuan pemahaman matematis memang merupakan kemampuan berpikir tingkat rendah (Pamungkas \& Afriansyah, 2017) akan tetapi kemampuan ini merupakan dasar dan pendukung untuk kemampuan- kemampuan matematis lainnya. Hal ini terlihat dari beberapa hasil penelitian, Wahyudin (Amam, 2013) berpendapat bahwa, "Kemampuan matematika siswa kita masih sangat rendah". Selain itu menurut Rahmah, dkk, (Junaidah,2015) rendahnya kualitas pemahaman matematis siswa disebabkan oleh proses pembelajaran dimana guru terlalu berkonsentrasi pada latihan soal yang bersifat prosedural sehingga tidak memungkinkan siswa cepat memperoleh makna dari kegiatan pembelajaran. Rendahnya kemampuan pemahaman matematis siswa ini merupakan salah satu masalah dalam pembelajaran matematika sehingga hal ini akan berpengaruh pada hasil belajar matematika siswa (Nuraeni \& Afriansyah, 2016). Oleh karena itu, kemampuan pemahaman matematis sangat perlu untuk dikembangkan.

Menurut Driver (Alan \& Afriansyah, 2017), "Pemahaman adalah kemampuan untuk menjelaskan suatu situasi atau tindakan. Seseorang dikatakan paham, apabila ia dapat menjelaskan atau menerangkan kembali inti dari materi atau konsep yang diperolehnya secara mandiri". Selain itu, menurut Lestari dan Yudhanegara (2015), "Kemampuan pemahaman matematis adalah kemampuan menyerap dan memahami ide-ide matematika".

Pada penelitian ini, digunakan indikator kemampuan pemahaman matematis menurut Skemp yang mengacu pada indikator pemahaman menurut Kilpatrick dan Findell (Gani, 2016) yaitu: 1)

Mosharafa: Jumal Pendidikan Matematika Volume 8, Nomor 3, September 2019 Copyright $\odot 2019$ Mosharafa: Jurnal Pendidikan Matematika 
Menyatakan ulang sebuah konsep; 2) Mengklasifikasi objek-objek berdasarkan dipenuhi atau tidaknya persyaratan yang membentuk konsep tersebut; 3) Menerapkan konsep secara algoritma; dan 4) Memberikan contoh dari konsep yang dipelajari.

Dalam upaya mengembangkan kemampuan pemahaman matematis siswa maka guru perlu mengambil tindakan yang tepat. Seorang guru dituntut untuk kreatif (Afriansyah, 2017), dan dalam hal ini guru perlu mempertimbangkan model pembelajaran alternatif yang akan digunakan dikelas, model pembelajaran tersebut yaitu model pembelajaran Auditory Intellectually Repetition dan kooperatif tipe Student Teams Achievements Division.

Menurut Juliati (2013), "Model pembelajaran Auditory Intellectualy Repetition adalah model pembelajaran dimana guru sebagai fasilitator dan siswa aktif dalam menggunakan inderanya untuk membangun sendiri pengetahuannya". Menurut Shoimin (2014), langkah-langkah pelaksanaan model pembelajaran Auditory Intelectually Repetition yaitu: 1) Siswa dibagi menjadi beberapa kelompok, masing-masing kelompok terdiri dari 4-5 anggota; 2) Siswa mendengarkan dan memperhatikan penjelasan dari guru; 3) Setiap kelompok mendiskusikan tentang materi yang mereka pelajari dan menuliskan hasil diskusi tersebut dan selanjutnya untuk dipresentasikan di depan kelas (Auditory); 4) Saat diskusi berlangsung, siswa mendapat soal atau permasalahan yang berkaitan dengan materi; 5) Masing-masing kelompok memikirkan cara menerapkan hasil diskusi serta meningkatkan kemampuan mereka untuk menyelesaikan masalah (Intelectually); dan 6) Setelah selesai berdiskusi, siswa mendapat pengulangan materi dengan cara mendapatkan tugas atau kuis untuk tiap individu (Repetition). Pada penelitian Azizah dan Sundayana (2016) diperoleh hasil kemampuan awal dan kemampuan akhir siswa menghasilkan pencapaian kemampuan pemecahan masalah matematis yang sama, namun peningkatan kemampuan pemecahan masalah matematis pada kelas AIR mendapatkan peningkatan yang sedang.

Menurut Huda (2014) model pembelajaran Student Teams Achievement Division) merupakan salah satu strategi pembelajaran kooperatif yang didalamnya beberapa kelompok kecil siswa dengan level kemampuan akademik yang berbedabeda saling bekerja sama untuk menyelesaikan tujuan pembelajaran. Tidak hanya secara akademik, siswa juga dikelompokkan secara beragam berdasarkan gender, ras dan etnis. Menurut Rusman (2012) langkah-langkah model pembelajaran kooperatif tipe Student Teams Achievement Division, yaitu: 1) Penyampaian tujuan dan motivasi; 2) Pembagian kelompok; 3) Presentasi dari guru; 4) Kegiatan belajar tim (kerja tim); 5) Kuis (evaluasi); dan 6) Penghargaan prestasi tim.

Beberapa penelitian sebelumnya telah menerapkan STAD pada penelitiannya 
dikaitkan dengan: kemampuan pemecahan masalah matematis (Nurhaeni \& Basuki, 2013; Wahyudi \& Rahadi, 2013; Yasa \& Madio, 2014); kemampuan komunikasi matematis (Nurbayani \& Nanang, 2013; Maulani \& Sundayana, 2017); dan hasil belajar matematika (Putri \& Sutriyono, 2018).

Model pembelajaran Auditory, Intelectually, Repetition dan kooperatif tipe Student Teams Achievement Division merupakan model pembelajaran yang menekankan dan mengarahkan siswa untuk lebih aktif dalam pembelajaran sedangkan guru sebagai fasilitator. Selain itu, ada keterkaitan antara kedua model pembelajaran tersebut dengan kemampuan pemahaman matematis jika dilihat dari sintak-sintaknya, yaitu pada penyampaian materi oleh guru, siswa bisa memperoleh pemahaman mengenai materi yang disampaikan, kemudian pada saat siswa berdiskusi kelompok, siswa yang belum paham mengenai materi dapat berdiskusi dan saling bertukar pikiran dalam kelompok sehingga dapat membantu siswa yang belum paham.

Berdasarkan uraian di atas, timbul gagasan dari peneliti untuk mengadakan penelitian pembelajaran matematika dengan judul "Perbandingan kemampuan pemahaman matematis antara siswa yang mendapatkan model pembelajaran Auditory Intelectually Repetition dan kooperatif tipe Student Teams Achievement Division".

Peneliti memiliki harapan untuk mengetahui perbandingan pengaruh yang 518 diberikan kedua model pembelajaran terhadap kemampuan pemahaman matematis siswa. Oleh karena itu, pokok permasalahan penelitiannya adalah: Apakah kemampuan pemahaman matematis siswa yang mendapatkan model pembelajaran Auditory Intelectually Repetition lebih baik daripada siswa yang mendapatkan model pembelajaran kooperatif tipe Student Teams Achievement Division?

\section{Metode}

Dalam penelitian ini, metode yang digunakan oleh peneliti adalah metode kuasi eksperimen. dengan desain penelitian nonequivalent control group design (Ruseffendi, 2003).

$\begin{array}{ccc}0 & X_{1} & 0 \\ - & \end{array}$

Keterangan:

0 = Tes awal (pretest) dan tes akhir (posttest)

$X_{1}=$ Perlakuan dengan model pembelajaran Auditory Intelectually Repetition

$X_{2}=$ Perlakuan dengan model pembelajaran kooperatif tipe Student Teams Achievement Division --- = Subjek (siswa)

Dengan sampel sebanyak dua kelompok, Kelompok pertama diberikan perlakuan model pembelajaran Auditory Intelectually Repetition sebagai kelas eksperimen I dan kelompok kedua diberikan perlakuan model pembelajaran kooperatif tipe Student Teams 
Achievement Division sebagai kelas berlangsung terinci pada tabel 1 berikut.

eksperimen II. Kedua kelompok tersebut terlebih dahulu diberi tes awal (pretest). Adapun tujuan utama diberikannya tes awal yaitu untuk mengetahui kemampuan awal, baik kelas eksperimen I maupun kelas eksperimen II. Setelah proses pembelajaran selesai, peneliti memberikan tes akhir (posttest).

Populasi dalam penelitian ini adalah siswa kelas VII yang terdiri dari 5 kelas. Dan kelas yang digunakan adalah kelas VIID dengan jumlah siswa sebanyak 30 siswa dan VII-E dengan jumlah siswa sebanyak 29 siswa di SMP Negeri 2 Leuwigoong. Adapun kegiatan selama penelitian

\section{Hasil dan Pembahasan}

\section{A. Hasil Penelitian}

Penelitian ini dilakukan terhadap dua sampel kelas yang saling bebas atau dua sampel dengan subjek yang berbeda dan mengalami perlakuan yang berbeda pula yaitu kelas eksperimen 1 menggunakan model pembelajaran Auditory Intelectually Repetition sedangkan kelas eksperimen 2 menggunakan model pembelajaran kooperatif tipe Student Teams Achievement Division. Selanjutnya akan dibahas mengenai pengolahan data hasil penelitian berupa data hasil pretest, gain

Tabel 1.

Jadwal Kegiatan Penelitian

\begin{tabular}{|c|c|c|c|c|}
\hline No & Waktu & Jam & Kegiatan & Materi \\
\hline 1. & Jumat, 6 april 2018 & $07.55-09.15$ & Uji coba di kelas VIII-D & - \\
\hline 2. & Selasa, 17 april 2018 & $07.25-09.25$ & Pretest di kelas eksperimen 2 & - \\
\hline 3. & Kamis, 19 april 2018 & $08.45-10.05$ & Pretest di kelas eksperimen 1 & - \\
\hline \multirow[t]{2}{*}{4.} & \multirow[t]{2}{*}{ Jumat, 20 april 2018} & $07.55-09.15$ & $\begin{array}{l}\text { Pembelajaran di kelas } \\
\text { ekperimen } 1\end{array}$ & $\begin{array}{l}\text { Mengenal dan } \\
\text { memahami jenis- } \\
\text { jenis segiempat. }\end{array}$ \\
\hline & & $09.15-10.35$ & $\begin{array}{l}\text { Pembelajaran di kelas } \\
\text { ekperimen } 2\end{array}$ & $\begin{array}{l}\text { Mengenal dan } \\
\text { memahami jenis- } \\
\text { jenis segiempat. }\end{array}$ \\
\hline \multirow[t]{2}{*}{5.} & \multirow[t]{2}{*}{ Jumat, 27 april 2018} & $07.55-09.15$ & $\begin{array}{l}\text { Pembelajaran di kelas } \\
\text { eksperimen } 1\end{array}$ & $\begin{array}{l}\text { Persegi panjang } \\
\text { dan persegi. }\end{array}$ \\
\hline & & $09.15-10.35$ & $\begin{array}{l}\text { Pembelajaran di kelas } \\
\text { eksperimen } 2\end{array}$ & $\begin{array}{l}\text { Persegi panjang } \\
\text { dan persegi. }\end{array}$ \\
\hline 6. & Kamis, 03 Mei 2018 & $08.45-11.05$ & $\begin{array}{l}\text { Pembelajaran di kelas } \\
\text { eksperimen } 1\end{array}$ & $\begin{array}{l}\text { Belah ketupat dan } \\
\text { layang-layang. }\end{array}$ \\
\hline \multirow[t]{2}{*}{7.} & \multirow[t]{2}{*}{ Jumat, 04 Mei 2018} & $07.55-09.15$ & $\begin{array}{l}\text { Pembelajaran di kelas } \\
\text { eksperimen } 1\end{array}$ & $\begin{array}{l}\text { Jajargenjang dan } \\
\text { trapesium. }\end{array}$ \\
\hline & & $09.15-10.35$ & $\begin{array}{l}\text { Pembelajaran di kelas } \\
\text { eksperimen } 2\end{array}$ & $\begin{array}{l}\text { Belah ketupat dan } \\
\text { layang-layang. }\end{array}$ \\
\hline 8. & Selasa, 08 Mei 2018 & $07.25-09.25$ & $\begin{array}{l}\text { Pembelajaran di kelas } \\
\text { eksperimen } 2\end{array}$ & $\begin{array}{l}\text { Jajargenjang dan } \\
\text { trapesium. }\end{array}$ \\
\hline \multirow[t]{2}{*}{9.} & \multirow[t]{2}{*}{ Jumat, 11 Mei 2018} & $07.55-09.15$ & Posttest kelas eksperimen 1 & - \\
\hline & & $09.15-10.35$ & Posttest kelas eksperimen 2 & - \\
\hline 10. & Senin, 14 Mei 2018 & $07.55-08.30$ & Angket di kelas eksperimen 1 & - \\
\hline 11. & Selasa, 15 Mei 2018 & $07.25-08.05$ & Angket di kelas eksperimen 2 & - \\
\hline
\end{tabular}


mutlak, gain ternormalisasi dan hasil angket.

Dari hasil penelitian dengan memberikan perlakuan terhadap dua kelas, dengan jumlah siswa sebanyak 65 orang. Dari 65 siswa hanya 59 yang diolah. 6 orang tidak diikut sertakan dikarenakan tidak memenuhi syarat, seperti tidak mengikuti pretest dan posttest. Dari 59 siswa diantaranya 30 siswa kelas eksperimen 1 dan 29 siswa dari kelas eksperimen 2 (lihat tabel 2).

Hasil analisis terhadap data pretest dari kelas Auditory Intelectually Repetition dan kooperatif tipe Student Teams Achievement Division diperoleh bahwa hasil uji normalitas data kedua kelas tersebut berdistribusi normal, maka untuk pengujian selanjutnya dilakukan uji homogenitas dua varians. setelah dilakukan perhitungan, diperoleh bahwa kedua varians homogen. Selanjutnya untuk menguji kesamaan dua rata-rata kemampuan awal siswa adalah dengan melakukan uji t.

Setelah dilakukan analisis ternyata

Tabel 2.

Statistik Deskriptif Kemampuan Pemahaman Matematis

\begin{tabular}{|ccccc|}
\hline \multirow{1}{*}{ Besaran } & \multicolumn{3}{c}{ AIR } & \multicolumn{2}{c}{ STAD } \\
\cline { 2 - 5 } & Pretest & Posttest & Pretest & Posttest \\
\hline $\mathrm{N}$ & 30 & 30 & 29 & 29 \\
\hline Skor Ideal & 24 & 24 & 24 & 24 \\
\hline $\begin{array}{c}\text { Skor } \\
\text { Terbesar }\end{array}$ & 18 & 24 & 18 & 24 \\
\hline $\begin{array}{c}\text { Skor } \\
\text { Terkecil }\end{array}$ & 1 & 8 & 1 & 5 \\
\hline Persentase & $47,08 \%$ & $75,83 \%$ & $37,36 \%$ & $72,84 \%$ \\
\hline Rata-Rata & 11,300 & 18,200 & 8,966 & 17,483 \\
\hline $\begin{array}{c}\text { Simpangan } \\
\text { Baku }\end{array}$ & 3,669 & 4,353 & 4,531 & 4,997 \\
\hline
\end{tabular}

diperoleh kesimpulan bahwa terdapat perbedaan kemampuan awal pemahaman matematis antara siswa yang mendapatkan model pembelajaran Auditory Intelectually Repetition dan kooperatif tipe Student Teams Achievement Division. Karena terdapat perbedaan kemampuan awal, maka dilanjutkan ke analisis data gain mutlak.

Hasil analisis gain mutlak dari kelas Auditory Intelectually Repetition dan kooperatif tipe Student Teams Achievement Division diperole bahwa hasil uji normalitas data kedua kelas berdistribusi normal dan dilanjutkan dengan uji homogenitas. Setelah dilakukan perhitungan, diperoleh bahwa kedua varians homogen. Selanjutnya untuk menguji kesamaan dua rata-rata kemampuan awal siswa adalah dengan melakukan uji t. sebelum menganalisis uji t maka perlu ditentukan terlebih dahulu rumusan hipotesisnya.

Setelah data dianalisis, diperoleh kesimpulan bahwa Kemampuan pemahaman matematis antara siswa yang mendapatkan model pembelajaran Auditory Intelectually Repetition tidak lebih baik daripada siswa yang mendapatkan model pembelajaran kooperatif tipe Student Teams Achievement Division.

\section{B. Pembahasan}

Kelas dengan model pembelajaran Auditory Intelectually Repetition dan Student Teams Achievement Division memiliki tahapan yang hampir sama. 
Adapun tahapan dari kedua model tersebut, yaitu pada tahapan ke satu model Auditory Intelectually Repetition, guru membagikan siswa kedalam kelompok belajar 5-6 orang. Sedangkan tahapan pertama pada model pembelajaran Student Teams Achievement Division, yaitu guru menyampaikan tujuan pembelajaran dan memotivasi siswa untuk mengikuti pembelajaran dengan baik. Hal ini dapat terlihat dalam gambar 1 dan 2 .

Adapun tahap kedua model pembelajaran Auditory Intelectually Repetition yaitu, guru menyampaikan materi pelajaran yang akan dipelajari, kemudian siswa menyimak dan memperhatikan guru dalam menyelesaikan materi pelajaran. Sedangkan pada model Student Teams Achievement Division, guru membagi siswa menjadi beberapa kelompok yang terdiri

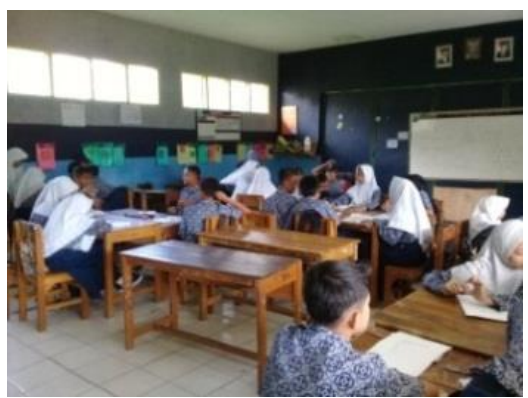

Gambar 1. Kegiatan Pembelajaran Tahap Satu Kelas Eksperimen 1

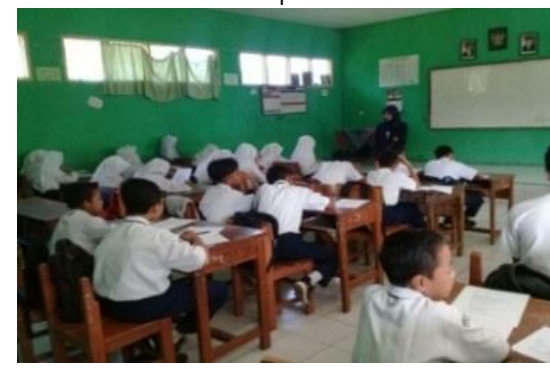

Gambar 2. Kegiatan Pembelajaran Tahap Satu Kelas Eksperimen 2 dari 5-6 orang. Hal ini dapat terlihat dalam gambar 3 dan 4.

Tahap ketiga model pembelajaran Auditory Intelectually Repetition, guru membagikan lembar kerja siswa (LKS) untuk dikerjakan secara berkelompok dan siswa mengerjakannya. Sedangkan pada model Student Teams Achievement Division, guru menyampaikan materi pelajaran yang akan dipelajari, kemudian siswa menyimak dan memperhatikan guru dalam menyelesaikan materi pelajaran. hal ini terlihat pada gambar 5 dan 6 .

Tahap keempat model pembelajaran Auditory Intelectually Repetition, perwakilan kelompok mempresentasikan hasil diskusinya. Sedangkan pada model Student Teams Achievement Division, guru membagikan lembar kerja siswa untuk dikerjakan secara berkelompok, guru memberikan bimbingan saat siswa

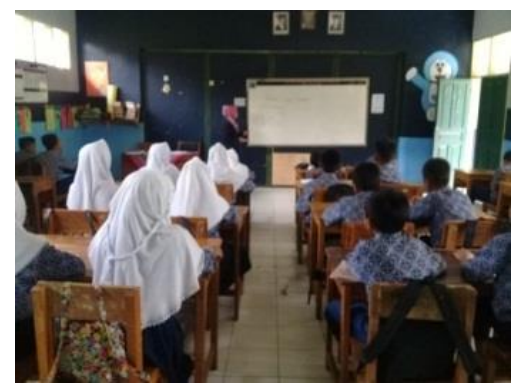

Gambar 3. Kegiatan Pembelajaran Tahap Dua Kelas Eksperimen 1

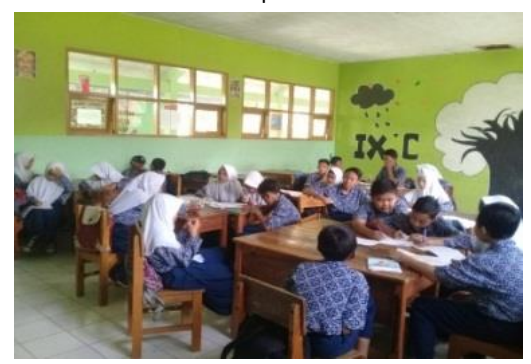

Gambar 4. Kegiatan Pembelajaran Tahap Dua Kelas Eksperimen 2

Mosharafa: Jurnal Pendidikan Matematika 
berdiskusi dan membahas lembar kerja siswa bersama-sama dengan siswa. Hal ini terlihat pada gambar 7 dan 8 .

Tahap kelima model pembelajaran Auditory Intelectually Repetition, yaitu guru memberikan pengulangan materi kepada siswa dengan cara memberikan lembar evaluasi diri dan tugas rumah. Sedangkan Tahap kelima pada model Student Teams Achievement Division, guru memberikan kuis kepada siswa untuk dikerjakan secara individu. Hal ini terlihat pada gambar 9 dan 10.

Secara keseluruhan kekurangan siswa dalam melaksanakan pembelajaran ini diakibatkan siswa masih merasa asing dan belum terbiasa belajar matematika dengan menggunakan model pembelajaran baik dengan model Auditory Intelectually

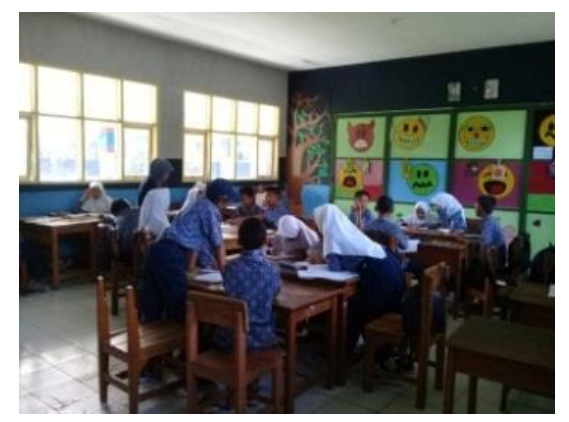

Gambar 5. Kegiatan Pembelajaran Tahap Tiga Kelas Eksperimen 1

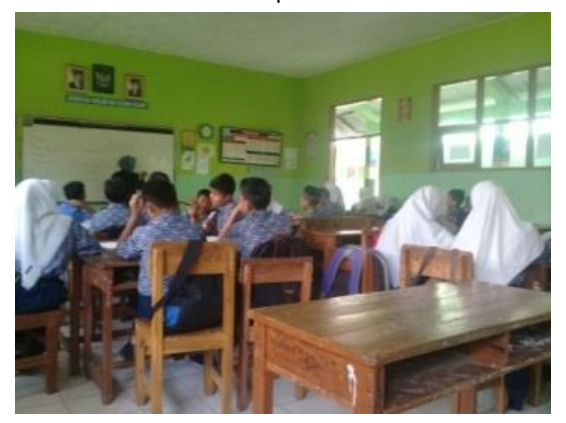

Gambar 6. Kegiatan Pembelajaran Tahap Tiga Kelas Eksperimen 2
Repetition ataupun model Student Teams Achievement Division. Hal tersebut dikarenakan siswa selalu belajar dengan model pembelajaran konvensional berupa ceramah dan tanya jawab, serta terlalu berpusat di guru, sehingga siswa kurang

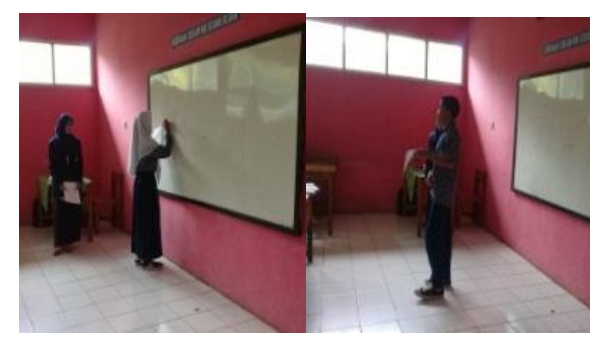

Gambar 7. Kegiatan Pembelajaran Tahap Empat Kelas Eksperimen 1

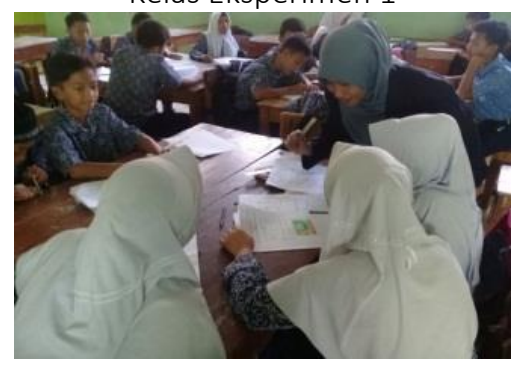

Gambar 8. Kegiatan Pembelajaran Tahap Empat Kelas Eksperimen 2

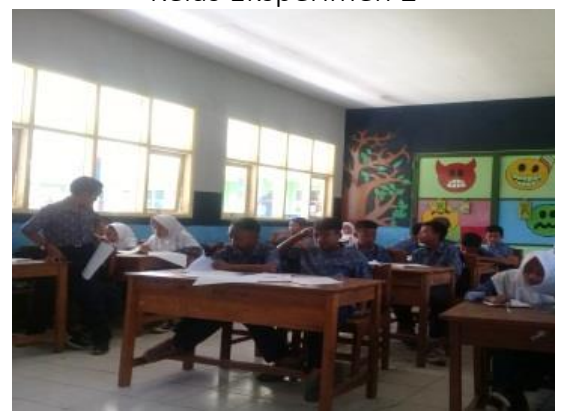

Gambar 9. Kegiatan Pembelajaran Tahap Lima Kelas Eksperimen 1

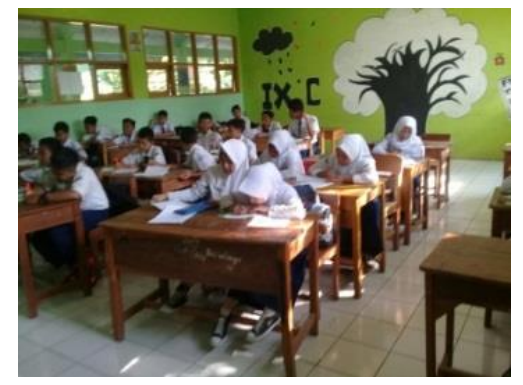

Gambar 10. Kegiatan Pembelajaran Tahap Lima Kelas Eksperimen 2

Mosharafa: Jurnal Pendidikan Matematika Volume 8, Nomor 3, September 2019 Copyright $\odot 2019$ Mosharafa: Jurnal Pendidikan Matematika 
aktif dalam pembelajaran. Sehingga ketika diberikan model pembelajaran dengan model Auditory Intelectually Repetition ataupun model Student Teams Achievement Division siswa merasa asing dan cenderung kurang dapat mengikuti alur pembelajaran yang diterapkan pada awal pertemuan.

Jika dilihat dari langkah-langkah model pembelajaran yang digunakan terdapat beberapa perbedaan yaitu jika dalam model Auditory Intelectually Repetition terdapat presentasi dan pengulangan materi sehinga siswa dapat meningkatkan kemampuan pemahamannya selain dari penyampaian guru, siswa bisa memperoleh pemahaman dari berdiskusi kelompok dengan cara mengerjakan soalsoal kemudian mengungkapkan pendapat atas apa yang menjadi hasil kelompoknya. sedangkan pada model Student Teams Achievement Division terdapat kuis diakhir pembelajaran sehingga siswa selain bisa memperoleh pemahaman dari penyampaian materi oleh guru, siswa juga dapat melatih kemampuan pemahamannya melalui kuis. Sehingga hal tersebut menjadikan kedua model tersebut mempunyai keunggulan masingmasing. Selama proses pembelajaran, siswa yang mendapatkan model Auditory Intelectually Repetition dan Student Teams Achievement Division secara keseluruhan berperan aktif dan menunjukkan sikap yang positif meskipun ada beberapa siswa yang nakal seperti berisik, mengganggu temannya dan pada saat berkelompok mengerjakan lembar kerja siswa ada kelompok dengan siswa yang pintar mengerjakannya sendiri tanpa berdiskusi dengan kelompoknya, tetapi hal itu bisa peneliti atasi dengan mengingatkan kepada siswa atau kelompoknya untuk mengerjakan secara berkelompok.

Dari hasil pengamatan peneliti selama pelaksanaan penelitian berlangsung, ada beberapa penyebab yang menjadikan model Auditory Intelectually Repetition tidak lebih baik daripada model pembelajaran Student Teams Achievement Division, hal ini bisa dilihat dalam langkahlangkah pembelajaran. kedua model tersebut yang memiliki tahapan yang hampir sama, yaitu sebagai berikut:

a. Pada awal pembelajaran guru menyampaikan materi terlebih dahulu.

b. Kedua model pembelajaran tersebut menggunakan metode pembelajaran diskusi atau berkelompok.

c. Kedua model pembelajaran tersebut sama-sama menggunakan lembar kerja siswa dalam pembelajarannya.

Selain itu, bisa juga dilihat dari kualitas peningkatan kemampuan pemahaman matematisnya, untuk kualitas peningkatan kemampuan model Auditory Intelectually Repetition diperoleh nilai rata-ratanya 0,56 dan berinterpretasi sedang. Dan untuk kualitas peningkatan kemampuan model kooperatif tipe Student Teams Achievement Division diperoleh nilai rataratanya 0,59 dan berinterpretasi sedang. Selain itu sikap siswa terhadap pembelajaran matematika dengan menggunakan model pembelajaran Auditory Intelectually Repetition dan 
kooperatif tipe Student Teams pembelajaran Auditory Intellectualy Achievement Division menunjukkan sikap Repetition (AIR) dapat mempengaruhi positif dengan berinterpretasi baik. Sehingga hal ini mendukung bahwa model Auditory Intelectually Repetition tidak lebih baik dari model kooperatif tipe Student Teams Achievement Division.

Peneliti berpendapat bahwa dalam penelitian ini menemukan beberapa kendala dalam melaksanakan penelitian diantaranya adalah sebagai berikut:

a. Siswa belum terbiasa dengan pembelajaran Auditory Intelectually Repetition dan Student Teams Achievement Division, maka pada saat pertama kali diperkenalkan siswa masih sulit dikondisikan.

b. Siswa merasa kurang senang disatukan dalam sebuah kelompok yang heterogen, karena mereka tidak terbiasa bekerja sama dengan siswa yang berbeda kemampuan belajarnya.

c. Dalam mengisi lembar kerja siswa yang harusnya dilakukan secara berkelompok, namun pada pelaksanaannya ada yang mengerjakannya sendiri tanpa berdiskusi dengan kelompoknya.

d. Ada beberapa siswa yang tidak masuk sekolah.

e. Ketika pembelajaran berlangsung, ada siswa yang nakal seperti berisik, ngobrol atau mengganggu temannya.

Namun terlepas dari kendala dalam penelitian tersebut, tidak terlalu menghambat jalannya penelitian.

Penelitian ini sejalan dengan penelitian Fitri dan Utomo (2016) yaitu model 524 kemampuan pemahaman konsep siswa kelas VIII di SMP Pustek Serpong. Senada pula dengan penelitian Yulanda dan Fauzan (2014), hasil dari penelitiannya yaitu perkembangan pemahaman konsep siswa cenderung meningkat setelah diterapkan model pembelajaran kooperatif tipe Student Teams Achievement Division (STAD) terutama pada indikator pemahaman konsep, yaitu menggunakan, memanfaatkan, dan memilih prosedur atau operasi tertentu serta mengaplikasikan konsep atau algoritma ke pemecahan masalah.

\section{Penutup}

Berdasarkan hasil penelitian dan pembahasan secara keseluruhan, diperoleh kesimpulan bahwa kemampuan pemahaman matematis antara siswa yang mendapatkan model pembelajaran Auditory Intelectually Repetition tidak lebih baik daripada siswa yang mendapatkan model pembelajaran kooperatif tipe Student Teams Achievement Division. Kualitas peningkatan kemampuan pemahaman matematis kedua kelas berinterpretasi sedang dan sikap siswa di kedua kelas terhadap pembelajaran matematika menunjukan interpretasi baik.

\section{Daftar Pustaka}

Alan, U. F., \& Afriansyah, E. A. (2017). Kemampuan Pemahaman Matematis Siswa Melalui Model Pembelajaran Auditory Intellectualy Repetition dan 
Problem Based Learning. Mosharafa: Jurnal Pendidikan Matematika, 11(1), 68-78.

https://doi.org/10.22342/jpm.11.1.38 90.67-78

Amam A. (2013). Pengaruh Pembelajaran Matematika Berbasis ICT Terhadap Kemampuan Pemahaman Dan Pemecahan Masalah Matematis Siswa SMP. Universitas Pendidikan Indonesia.

Azizah, G. N., \& Sundayana, R. (2016). Kemampuan Pemecahan Masalah Matematis dan Sikap Siswa terhadap Model Pembelajaran Kooperatif Tipe Air dan Probing-Prompting. Mosharafa: Jurnal Pendidikan Matematika, 5(3). 305-314. DOI: https://doi.org/10.31980/mosha rafa.v5i3.285

Ferdianto, F. \& Ghanny. (2014). Meningkatkan Kemampuan Pemahaan Matematis Siswa Melalui Problem Posing. Jurnal Euclid, 1(1). 47-54.

Fitri, S., \& Utomo, R. (2016). Pengaruh Model Pembelajaran Auditory, Intellectualy, And Repetition (AIR) Terhadap Kemampuan Pemahaman Konsep di SMP Pustek Serpong. Jurnal E-DuMath, 2(2). 193-201.

Gani, D. A. (2016). Pengaruh Penggunaan Metode Pembelajaran Buzz Terhadap Kemampuan Pemahaman Matematis Pada Siswa SMA. UNPAS.

Huda, M. (2014). Model-Model Pengajaran dan Pembelajaran. Yogyakarta: Pustaka Pelajar.
Juliati, S. (2013). Pengaruh Penerapan Model Pembelajaran Auditory Intellectually Repetition (AIR) terhadap Kemampuan Komunikasi Matematika Siswa MTsN Pekanbaru. UIN SUSKA Riau.

Junaidah. (2015). Meningkatkan Kemampuan Pemahaman, Komunikasi, dan Disposisi Matematika Siswa SMP Melalui Pendekatan Konstekstual. UPI.

Lestari, K. E \& Yudhanegara, M. R. (2015). Penelitian Pendidikan matematika. Bandung: Refika Aditama.

Maulani, L., \& Sundayana, R. (2017). Perbedaan Kemampuan Komunikasi Matematis antara Siswa yang Mendapatkan Model Pembelajaran Learning Cycle 5e dengan Student Teams Achievement Division. Mosharafa: Jurnal Pendidikan Matematika, 6(2). 217-228. DOI: https://doi.org/10.31980/mosha rafa.v6i2.309

Nuraeni, Y., \& Afriansyah, E. A. (2016). Peningkatan Kemampuan Pemahaman Matematis Siswa Melalui Pembelajaran Kooperatif Tipe Rotating Trio Exchange. Jurnal Inovasi Pendidikan Dasar, 1(2). 85-94.

Nurbayani, Y., \& Nanang, N. (2013). Perbedaan Kemampuan Komunikasi Matematik Siswa antara yang Mendapatkan Pembelajaran Kooperatif Tipe Numbered Heads Together dengan Student Teams Achievement Divisions. Mosharafa: Jurnal Pendidikan Matematika, 2(3). 
203-212.

Nurhaeni, K., \& Basuki, B. (2013).

Perbedaan Kemampuan Pemecahan Masalah Matematik Siswa antara yang Menggunakan Metode Student Teams Achievement Division dengan Teams Games Tournament. Mosharafa: Jurnal Pendidikan Matematika, 2(1). 23-36.

Pamungkas, Y., \& Afriansyah, E. A. (2017). Aptitude Treatment Interaction Terhadap Kemampuan Pemahaman Matematis Siswa. Jurnal Pendidikan Matematika RAFA, 3(1). 122-130.

Putri, K. C., \& Sutriyono, S. (2018). Pengaruh Metode Pembelajaran Stad Terhadap Hasil Belajar Matematika pada Siswa Kelas VIII. Mosharafa: Jurnal Pendidikan Matematika, 7(2). 295-306.

DOI: https://doi.org/10.31980/mosha rafa.v7i2.358

Ruseffendi, E. (2003). Dasar-Dasar Penelitian dan Bidang Non-Eksakta lainnya. Semarang: Unnes Pres.

Shoimin, A. (2014). 68 Model Pembelajaran INOVATIF dalam Kurikulum 2013. Yogyakarta: Ar-Ruzz media.

Soemarmo, U., \& Hendriana, H. (2014). Penilaian Pembelajaran Matematika. Bandung: PT Refika Aditama.

Wahyudi, T., \& Rahadi, M. (2013). Perbedaan Kemampuan Pemecahan Masalah Matematika Siswa Melalui Penerapan Metode Pembelajaran STAD dengan Siswa yang Menggunakan Metode Pembelajaran
Jigsaw. Mosharafa: Jurnal Pendidikan Matematika, 2(2). 123-134.

Yasa, Y., \& Madio, S. S. (2014). Perbedaan Kemampuan Pemecahan Masalah Matematika antara Kelompok Siswa yang Mendapatkan Pembelajaran Kooperatif Tipe Teams Games Tournament (TGT) dengan Student Teams Achievements Divisions (STAD). Mosharafa: Jurnal Pendidikan Matematika, 3(2). 121-132.

Yulanda, N., \& Fauzan, A. (2014). Pengaruh Model Pembelajaran Kooperatif Tipe Student Teams Achievement Division (STAD) terhadap Pemahaman Konsep Matematika Siswa Kelas VII SMPN 3 Padang, Jurnal Pendidikan Matematika, 3(1). 61-67.

\section{Riwayat Hidup Penulis}

Noni Siti Ridia, S.Pd.

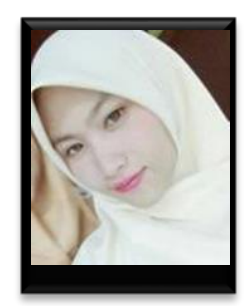

Lahir di Garut, 21 Mei 1996. Studi S1 bidang Pendidikan Matematika IPI, Garut 2018.

\section{Ekasatya Aldila Afriansyah, M.Sc.}

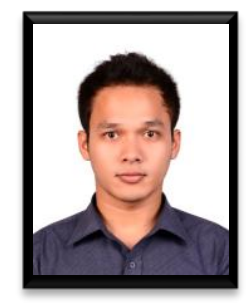

Lahir di Bandung, 4 April 1986. Dosen Tetap Yayasan STKIP Garut. Studi S1 Matematika Konsentrasi Statistika UPI, Bandung, lulus tahun 2009; S2 Pendidikan Matematika UNSRIUTRECHT, PalembangUtrecht, lulus tahun 2012; dan S3 Pendidikan Matematika UPI, Bandung, sampai sekarang. 